\title{
22: 28967302-28960997
}

National Cancer Institute

\section{Source}

National Cancer Institute. 22:28967302-28960997. NCI Thesaurus. Code C45093.

Physical location of LIF_Gene 